\title{
Utilization of some cereals and legumes as coating materials during frying chicken fillet
}

\author{
Hayat Hashem Abd-Elsattar, Sohair Taher El-Hadidie, Maha Mounier Tawfik \\ Food Technology Research Institute of Agriculture Research Centre, Giza, Egypt
}

Email address:

mahalouz@yahoo.com (M. M. Tawfik)

\section{To cite this article:}

Hayat Hashem Abd-Elsattar, Sohair Taher El-Hadidie, Maha Mounier Tawfik. Utilization of Some Cereals and Legumes as Coating Materials during Frying Chicken Fillet. International Journal of Nutrition and Food Sciences. Vol. 4, No. 1, 2015, pp. 8-13.

doi: 10.11648/j.ijnfs.20150401.12

\begin{abstract}
The present investigation was carried out to evaluate the seasoned powder coating mixture made from some legumes (lupine and chickpea) and some cereals (rice and corn). Three seasoned powders were prepared and compared with seasoned vegetar from local market as control. The three seasoned powders and vegetar were used as coaters of the chicken breast (fillets). Chemical analyses were determined in raw materials and fillets, which was coated with each of seasoned powders before and after frying. Fat absorption, cooking loss and cooking yield were determined in fillets after frying. Microbiological analyses as total count bacteria, yeast and mold and E.Coli were determined for each of seasoned powders and after frying during storage period. Moreover, sensory characteristics of fried fillets coated with each of seasoned powders were determined. The results showed that the seasoned legumes mixture powder contained the highest protein, fat, crude fiber and ash, 29.63, 7.0, 4.02, and 2.97 on wet weight, respectively followed by seasoned cereals and legumes mixture powder and seasoned cereals mixture powder. Moreover, before and after frying of chicken breast coated with seasoned powders, the results showed that the protein, fat, total carbohydrates increased after frying, whereas crude fiber and ash were decreased. These results occurred due to fat absorption, cooking loss and cooking yield. Microbiological analyses were determined for each of seasoned powders during storage period at room temperature. The results showed that the bacteria count fixed at the fifth dilution and at the third dilution for yeast and mould. Moreover, E.coli forming groups not detected in all samples of seasoned powders and control. Whereas, storage of fillets for a period at $-20^{\circ} \mathrm{C}$, showed the same results and manners for microbial analyses, as those of the different seasoned mixture powders, during storage period. The results of sensory characteristics of fried fillets, coated with the different types of seasoned mixture powders showed that the treatments No. 1, 2 and 3 had a significant variation for total acceptability (90.5, 91.2 and 92.4\%, respectively) with a slight decrease than vegetar control, (94.1\%). From the results, it was found that the seasoned powder prepared from legumes mixture gave the best results and sensory evaluation, followed by seasoned powder prepared from cereals and legumes mixture and seasoned powder prepared from cereals mixture. These different seasoned powders gave better results than vegetar control, obtained from local market. Therefore, these different seasoned powders can be used as natural coating materials for meat because of their safety and high nutritional values.
\end{abstract}

Keywords: Coating, Seasoned, Legumes, Cereals, Fillets

\section{Introduction}

Legumes are important source of proteins and other nutrients and commonly used as food particularly in developing countries. Legumes represent the major component of dietary foodstuff along as bread [1]. In Egypt, legumes represent the major Egyptian diets what over the standard of living [2]. The use of legumes assumes significance as cheap and concentrated source of protein compared with the high cost of protein of animal origin)[3].The genus lupines typically contain 36$52 \%$ protein, 5-20\% oil[4]. Lupine flour was added for its nutritive value high protein efficiency ratio and provide functional properties in bakery and pastry products. [5]. Lupine could use as a source of protein or fiber and for supplementation in existing or new products. Also, use lupine can in bread making, biscuits, pasta products, and a variety of other food products [6]. Chickpeas (Cicera 
rietinaum L.) are one of the oldest and most widely consumed legumes in the world. The seeds contain high levels of carbohydrates $(41.10-47.42 \%)$ and protein $(21.7-$ $23.40 \%)$. Starch is the major carbohydrates fraction, representing about (83.9\% of the total carbohydrates [7]. Rice is a great source of complex carbohydrates, which is an important source of the fuel bodies need. Rice has no fat, no cholesterol and is sodium free. Rice is an excellent to include in a balanced diet. It is good source of vitamins and minerals such as thiamine, niacin, iron, Riboflavin, vitamin D. [8]. Corn contains vitamin B-complex such as commendable for hair, skin, digestion, heart and brain. It contains vitamin $\mathrm{C}, \mathrm{A}$ and $\mathrm{K}$ together with large amount of beta-caroteneB1(thiamine), B2 (niacin), B3 (riboflavin), B5 (pantothenic acid) and B6 that makes it and fair amount of selenium that helps to improve thyroid gland and play important role in proper functioning of immune system. It has higher content of protein and fat as compared to other cereals [9]. Corn is an excellent source of carbohydrates with low crude fiber levels [10].Mixing legumes with some cereals, grains such as corn, wheat, barley were improving the nutritional quality of protein without significant changes in organoleptic quality of the product [11]. Spices and herbs played an important role in human life from prehistoric times. They have been use not only for flavoring foods but also for their anti-oxidative preservative and medical properties. The essential oils which act as antioxidant and antimicrobial agents are feasible materials because they are naturally flavoring materials, widely cultivated and inexpensive [12].The increasing preference for natural foods has obliged the food industry to include natural antioxidant in various products to delay oxidative degradation of lipids. Improve quality and nutritional value of foods and replace synthetic antioxidants. [13] [14].

Recently, consumers have rejected synthetic antioxidant because of their carcinogenicity [15] [16].Many herpes, spices and their extracts have been added in variety of foods to improve their sensory characteristics and extend shelf- life [17]. Gluten is the general name for one of the proteins found in wheat, barley and rye[18].

The aim of this study was carryout to evaluate some cereals (rice and corn) and legumes (lupine and chickpea) for preparation some different seasoned mixture powder as free gluten more suitable for celiac diseases. These different seasoned were used as a coating materials of chicken breast meat, the chemical analysis, microbiological analysis and sensory characteristics were determined for the raw and product materials.

\section{Materials and Methods}

\subsection{Materials}

Lupine, chickpea, rice and corn seeds were obtain from Filed Crops Research Institute, Agric. Res. Center, and Giza, Egypt.

The seeds were clean to remove dust, dirt, stubbles and foreign matters after that, it milled in Willy mill to give fine powder (60mesh), it was stored at room temperature until analyses. Chicken breast meat (fillets), sunflower oil, eggs, salt, lemon juice, spices (carry, ginger, turmeric and garlic) and vegetal (common seasoned flour coating mixture) were purchase from local market, Giza, Egypt. Total Plat Count agar, Maccounkey agar, Yeast and Mould agar Medias obtained from Difco Company.

\subsection{Methods}

\subsubsection{Preparation of Cereals and Legumes Mixture Powder}

The milled seeds (rice and corn ) and legumes(lupine and chickpea) were mixed in equal weight $(1: 1 \mathrm{w} / \mathrm{w})$ to product, mixed cereal powder, legumes powder $(1: 1 \mathrm{w} / \mathrm{w})$ and mixed cereal - legumes powder $(1: 1: 1: 1 \mathrm{w} / \mathrm{w} / \mathrm{w} / \mathrm{w})$.

\subsubsection{Preparation of Seasoned Flour Coating Mixture}

Spicy mixture contained $(20 \% \mathrm{w} / \mathrm{w})$ were carry, ginger, Garlic and turmeric was the ratio of (40:30:15:15) respectively was added to all the pervious seeds and or legume mixture powder to give the fallowing formulas:

1 - Seasoned cereals flour coating material.

2- Seasoned legumes flour coating mixture.

3- Seasoned (cereals, legumes) flour coating mixture.

Vegetal was use as a control without any addition.

\subsubsection{Preparation and Cooking the Chicken Breast (Fillets)}

The Chicken breast (fillets) was manually cut to small strips (fillet, 50-70 gm of each one), before cooking. Then marinated in salt and lemon juice for at least 2 hours then dipping in eggs [19],the breast strips were subject to one of four coating treatments, i.e, vegetar, cereals, legumes and cereals legumes mixture.

The first one the control treatment, while the Breast strips were coated with vegetal" from local market."

The three treatments of chicken breast strips were subjected to (No.1, No.2, andNo3) with coated, (Cereals, legumes, legumes and cereals) seasoning flour coater mixtures respectively. After that, all the previously treatment were frying in sun flour oil at $\left(180-200^{\circ} \mathrm{C}\right)$ for $6 \mathrm{~min}$. on each side until golden color, when the temperature of the fried samples were dropped to $60^{\circ} \mathrm{C}$, the samples were kept frozen after packaging till analysis [20].

\subsubsection{Analytical Methods}

Moisture, protein, crude fiber, ash, and fat content were determined according to[21] in vegetar, all seasoned flour coater mixture and in fillets as a row and before and after frying. Carbohydrates content was calculate by difference

The fat absorption (fat uptake) calculated according to the following formulas, Fat absorption $(\%)=(\mathrm{F}$ final- $\mathrm{F}$ initial $/ \mathrm{F}$ final) $\times 100$

Where $\mathrm{F}$ final and $\mathrm{F}$ initial are fillets fat content after and before frying respectively expressed as percentage on a dry basis according to [22].

\subsubsection{Cooking Loss}

Fillets cooked according to the method described by [20] 
and the cooking loss calculated from the following equation:

$\%$ cooking loss $=$ weigh of $($ raw- cooked/ weigh of raw $) \times 100$

\subsubsection{Microbiological Analysis}

Total bacteria count, yeast and mould, coli form group were determined according to [23].

\subsubsection{Sensory Evaluation}

The frying fillets were sensory evaluated for taste, color, odor, texture and overall acceptability by well-trained ten panelists of Food Technology Research Institute Agricultural Research Center according to [24].

\subsubsection{Statistical Analysis}

Data analyzed with GLM (General liner Model) program using statistical analysis system [25].

\section{Results and Desiccation}

\subsection{Chemical Composition of Different Seasoned Formula}

Table (1). Chemical composition of different seasoned formula on wet weight

\begin{tabular}{|c|c|c|c|c|c|c|}
\hline Treatment & Moisture & Protein & Fat & Crude fiber & Ash & Total carbohydrate \\
\hline VegetarControl & 7.07 & 10.00 & 1.42 & 10.60 & 2.26 & 68.65 \\
\hline Seasoned cereals mixture powder & 10.05 & 11.99 & 5.20 & 2.08 & 1.62 & 69.04 \\
\hline Seasoned legumes mixture powder & 8.07 & 29.63 & 7.00 & 4.02 & 2.97 & 48.31 \\
\hline Seasoned cereals and legumes mixture powder & 8.96 & 19.75 & 6.2 & 3.30 & 2.45 & 59.47 \\
\hline
\end{tabular}

Moisture, protein, fat, crude fiber, ash and total carbohydrates were determined in vegetar as a control, cereals, legumes and cereals -legumes mixture powder and the results are reported in table (1).

From the results, it could be notice that the seasoned legumes mixture powder contained the highest protein, fat, crude fiber and ash (29.63, 7.00, 4.02, and 2.97 on wet weight respectively). Followed by seasoned cereals and legumes mixture powder were $(19.75,6.20,3.30$, and 2.45 on wet weight respectively).Whereas, vegetar and seasoned cereals mixture powder had the highest content in total carbohydrates (68.65, 69.04, on wet weight respectively) and the lowest in protein, fat, and ash (10.00-11.99, 1.42-5.2 and 2.26-1.62 on wet weight respectively).

These results are agreement with,[1] who mentioned that, legumes are important source of protein and other nutrients. It contain up to $50 \%$ starch [26].Other side, corn is an excellent source of carbohydrates with low crude fiber levels [10].

\subsection{Chemical Composition of Raw and Seasoned Chicken Breast Fillets}

Table (2).Chemical composition of raw and seasoned chicken breast fillets before and after frying on wet weight

\begin{tabular}{|c|c|c|c|c|c|c|}
\hline Treatments & Moisture & Protein & Fat & Crude fiber & Ash & Carbohydrates \\
\hline $\begin{array}{l}\text { Row chicken breast fillet } \\
\text { Before cooking }\end{array}$ & 71.3 & 15.50 & 5.25 & 2.03 & 0.90 & 5.02 \\
\hline $\mathrm{C}^{*}$ & 66.40 & 20.50 & 5.14 & 2.26 & 2.10 & 3.63 \\
\hline $1 *$ & 65.00 & 19.70 & 5.06 & 3.60 & 1.10 & 3.54 \\
\hline $2 *$ & 69.60 & 22.60 & 5.62 & 5.90 & 2.20 & 1.02 \\
\hline $3 *$ & 61.70 & 22.00 & 5.64 & 4.10 & 1.28 & 3.68 \\
\hline \multicolumn{7}{|l|}{ After cooking } \\
\hline $1 * *$ & 40.00 & 29.80 & 19.80 & 1.80 & 0.47 & 8.13 \\
\hline $2 * *$ & 39.00 & 32.95 & 18.80 & 3.20 & 1.20 & 4.85 \\
\hline $3 * *$ & 35.90 & 31.30 & 21.10 & 2.07 & 0.67 & 8.96 \\
\hline
\end{tabular}

Where

C- Seasoned fillets coated with vegetar mixture (as a control)

1- Seasoned fillets coated with seasoned cereals mixture

2-Seasoned fillets coated with seasoned legumes mixture

3-Seasoned fillets coated with seasoned cereals and legumes mixture

* Before cooking** after cooking

Table (2) showed that chemical composition of raw and seasoned chicken breast fillets before and after frying. The raw chicken breast fillet characterized with the highest moisture content $(71.3 \%)$ fallowed by protein content $(15.5 \%)$, fat $(5.25 \%)$, carbohydrate $(5.02 \%)$, crude fiber $(2.03 \%)$ and ash $(0.9 \%)$. After chicken fillet marinated in salt and lemon juice, dipping in eggs and subjected for two hours of coating materials, chemical composition was conducted before and after frying. Before frying, the moisture content of coated fillet resulted in decrease in moisture content by about
13.5 to $2.4 \%$ according to the coating treatments. The decrease in moisture content may be due to the marinating in salt. Because of decreasing moisture content, all chemical composition increased compared to the raw material in a range of 27.1 to $45.8 \%, 3.6$ to $7.43 \%, 11.33 \%$ to $190.6 \%$ and 22.2 to $144 \%$ for protein, fat, crude fiber and ash, respectively. Meanwhile, total carbohydrate decreased by about $26.7 \%$ to 79.76 due to treatments. On the other hand, frying caused a dramatically decrease in moisture content (43.9\% to 51.9) than the raw fillet. Meanwhile, protein and 
fat increased by about two and 4 fold as that of raw ones. A slight increase and decrease found concerning crude fiber, ash and total carbohydrates. From the above mention, data, it could be conclude that frying chicken breast fillet decreased the moisture content and increase protein and fat content of the product and this may be due to the evaporation of moisture, which reflected increasing in other chemical composition and the fat absorption. The obtained results were in the line with the finding of other researchers [27], [28], and [29].

\subsection{Fat Absorption Cooking Loss percentage and Cooking Yield percentage of Fried (Cooked) Chicken Breast}

Table (3). Fat absorption, cooking loss percentage and cooking yield percentage of fried (cooked) chicken breast (fillets) on dry weight

\begin{tabular}{llll}
\hline Treatment & Fat absorption & Cooking loss & Cooking yield \\
\hline C & 56.75 & 35.20 & 64.80 \\
1 & 56.21 & 33.70 & 66.30 \\
2 & $40.00^{*}$ & $20.60^{*}$ & $79.40^{*}$ \\
3 & 55.25 & 32.00 & 68.00 \\
\hline
\end{tabular}

Table (3) showed that the percent of fat absorption cooking loss and cooking yield of fried chicken breast. Among all coating application, it could be observe that the vegetal treatment is highest in fat absorption $(56.75 \%)$, cooking loss $(35.10 \%)$ and lowest in cooking yield (64.80\%) on dry weight.

On other hand legumes coated breast fillet restricted less fat absorption (40\%), and cooking loss (20\%) and highest in cooking yield (79.40) on dry weight due to the presence of protein (in legumes mixture) apparently functioned as adhesion aids providing homogenous layer between substrate (fillets) and outer layer. This layer thermally gel rapidly at the frying temperature, formed a crust that inhibited fat penetration into and moisture loss from the food substrate, hence water loss and fat absorption were reduced during frying. Results partially agreed with those reported by [30].

\subsection{Microbial Analysis of Different Seasoned Mixture Powder}

Table (4) showed, the resultant total bacteria count, E.coli, and yeast and mould in different types of seasoned mixture powder. The results fixed at the fifth dilution for bacteria count and the third dilution for yeast and mould.

During the storage period, the control treatment showed a value of total count bacteria (ND, 0.002, $0.16 \times 10^{-5} \mathrm{CUF}$ ). While seasoned cereals, seasoned legumes and their mixture resulted in total count bacteria amounted $2.0 .5,0.1 \times 10^{-5} \mathrm{CUF}$ $50,2.5,0.35 \times 10^{-5} \mathrm{CUF}$ and $70,4,1.25 \times 10^{-5} \mathrm{WF}$, respectively for the same storage period.

Concerning yeast and mould it could be observe that the control treatment showed that the yeast and mould found in $\mathrm{ND}, 4.0$ and $7.0 \times 10^{-3}$ CUFduring storage period. While, all treatments resulted in 20,2.0, 0.25, 9.0, 1.0, 0.29and 18.0, 2.0, 0.34 CUF, respectively.

Moreover the E.coil was not detected in and all treatment. During the same storage period, the results showed an increase in the total count of bacteria and yeast and mould in the control treatment and decreased in all other formulas due to the presence

e of the spicy mixture, which added to all formulas except the control formula (vegetar).

These results are agreement with [31], [32]they found that, herpes and spices have been show to passes antimicrobial functions and could serve as a source for antimicrobial agent against food spoilage and pathogens.

Table (4). Microbial analysis of different seasoned mixture powder during storage at room temperature

\begin{tabular}{|c|c|c|c|c|c|c|c|c|c|}
\hline \multirow{2}{*}{ Treatment } & \multicolumn{3}{|c|}{ T. C. $\left(10^{-5}\right)$ CUF } & \multicolumn{3}{|c|}{$Y$ and $M\left(10^{-3}\right) C U F$} & \multicolumn{3}{|c|}{ E.coli $\left(10^{-1}\right)$ CUF } \\
\hline & Zero & 6 Month & 12 Month & Zero & 6 Month & 12 Month & Zero & 6 Month & 12 Month \\
\hline $\mathrm{C}$ & ND & 0.002 & 0.16 & ND & 4.0 & 7.0 & \multirow{4}{*}{ N.D } & & \\
\hline 1 & 2.0 & 0.5 & 0.10 & 20.0 & 2.0 & 0.25 & & & \\
\hline 2 & 50 & 2.5 & 0.35 & 9.0 & 1.0 & 0.29 & & & \\
\hline 3 & 4.0 & 4.0 & 1.25 & 18.0 & 2.0 & 0.34 & & & \\
\hline
\end{tabular}

Where

T.C Total bacteria count in the fifth dilution

$\mathrm{Y}$ and $\mathrm{M}$ Yeast and mould in the third dilution

E. coli in the first dilution

ND: not detected

\subsection{Microbial Analysis after Frying Chicken Breast}

Table (5) showed that no detectable counts for bacteria count, Y\&M, and E.coli concerning all treatments at zero time due to the high temperature used during cooking 180$200^{\circ} \mathrm{Cfor} 6 \mathrm{~min}$., which was enough to kill all microbial strains.

After 6 months of storage a high increase was observed in total count bacteria and yeast and mould for the control from $0.002,0.01 \times 10^{-3} \mathrm{CUF}$, and slightly increase was found regarding coating with cereals mixture powder compared to the other treatments which coated with legumes or cereals and legumes mix powder which reordered no detectable count.

The fried fillet coated with legume and cereal mixture results in non-detectable counts Yeast, mould, and E.Coli after 12 -month storage at $-18^{\circ} \mathrm{C}$. Meanwhile other treatments showed some infections 0.005 and $0.03,0.02$ and 3.0 CUF due to other coating materials. It is worth mentioning that vegetar treatments resulted in highest amounts of T.C. and yeast and mould being 70 and 20 CUF. E.Coli not detected concerning all treatments. It could be concluded that legumes 
and cereals, legumes mixture improved the quality of meat surface.

On other hand natural spices which, additives to all the treatment inhibited the microbial growth. These results agreement with[33], reviewed the function of butter and breading as food coatings, enhance food appearance, inhibit oxidation, retard penetration of external bacterial.

Table (5). Microbial analysis after frying chicken breast during storage period at $\left(-20^{\circ} \mathrm{C}\right)$

\begin{tabular}{|c|c|c|c|c|c|c|c|c|c|}
\hline \multirow{2}{*}{ Treatment } & \multicolumn{3}{|c|}{ T.C $\left(10^{-5}\right)$ CUF } & \multicolumn{3}{|c|}{$Y \& M\left(10^{-3}\right) C U F$} & \multicolumn{3}{|c|}{ E.coli $\left(10^{-1}\right)$ CUF } \\
\hline & Zero & 6 Month & 12 Month & Zero & 6 Month & 12 Month & Zero & 6 Month & 12 Month \\
\hline $\mathrm{C}$ & \multirow{4}{*}{ N.D } & 5.0 & 70 & \multirow{4}{*}{ N.D } & 0.15 & 20 & \multirow{4}{*}{ N. D } & & \\
\hline 1 & & 0.0002 & 0.03 & & 0.01 & 3.0 & & & \\
\hline 2 & & N.D & N.D & & N.D & N.D & & & \\
\hline 3 & & N.D & 0.005 & & N.D & 0.02 & & & \\
\hline
\end{tabular}

N.D: not detected

\subsection{Sensory Characteristics of Frying Fillets Coating Treated with Different Types of Coating Materials}

Table (6) showed the sensory characteristics of cooked fillets which treated with different types of coating materials. Tested characteristics included taste, color, texture and plasticity. Taste, odor, color resulted in non-significant difference between treatments and control ones. Texture and plasticity show that a significant decrease treatment (No.1) and non-significant decrease in treatment (No.2) respectively, Compared with the control treatment. This results is agreement with the data were in line with the finding of [33], the interaction and dubiety between ingredient of some types of coating materials, enhance food appearance, improve flavor retain crispness at last improving quality characteristics of frying chicken breast fillets.

Table (6). Sensory characteristics of frying fillets coating treated with different types of coating materials.

\begin{tabular}{|c|c|c|c|c|c|c|}
\hline Treated & Taste(20) & Oder(20) & Color (20) & Texture(20) & Plasticity(20) & All acceptability $(100)$ \\
\hline $\mathrm{C}$ & $18.9+1.52 \mathrm{a}$ & $18.9 \pm 1.19 a$ & $19 \pm 1.33 \mathrm{a}$ & $18.9 \pm 1.19 a$ & $19 \pm 1.05 \mathrm{a}$ & $94 \pm 5.14 \mathrm{a}$ \\
\hline 1 & $17.9 \pm 1.19 a$ & $18.8 \pm 0.91 \mathrm{a}$ & $18.5 \pm 126 a$ & $17.7 \pm 1.15 b$ & $17.8 \pm 0.91 b$ & $90.5 \pm 5.01 \mathrm{a}$ \\
\hline 2 & $18.3 \pm 1.56 \mathrm{a}$ & $18.1 \pm 1.28 \mathrm{a}$ & $18.3 \pm 1.56 \mathrm{a}$ & $18.2 \pm 0.91 \mathrm{ab}$ & $18.1 \pm 1.1 \mathrm{ab}$ & $91.2 \pm 3.55 \mathrm{a}$ \\
\hline 3 & $18.7 \pm 0.48 \mathrm{a}$ & $18.6 \pm 1.07 \mathrm{a}$ & $18.4 \pm 1.17 \mathrm{a}$ & $18.2 \pm 1.03 \mathrm{ab}$ & $18.5 \pm 0.97 \mathrm{ab}$ & $92.4 \pm 3.74 \mathrm{a}$ \\
\hline LSD at $5 \%$ & 1.1512 & 1.0230 & 1.2187 & 0.9819 & 0.9195 & 4.0125 \\
\hline
\end{tabular}

\section{Conclusion}

From the results, it could be recommended that the seasoned prepared from legumes mixture powder gave the best results and sensory evaluation followed by seasoned cereals and legumes mixture powder and seasoned made from cereals mixture powder. These different seasoned gave the best results than control vegetar obtained from local market. Therefore, the different seasoned can be used as a natural coating material of meat because of its safety and high nutrition value.

\section{References}

[1] Shalaby, A. R. (2000). Changes in biogenic amines in mature and germinating legumes seeds and their behavior during cooking. Nahrung, 44 (1): 23-27.

[2] Abd-Allah, M.A., Abu-Salem, F.M. and Ahmed, S. M. A. (1988).Relation between specific technological treatmentsm nutritive value and the HCN content of some common Egyptian legumes. Annals Agric.Sci.,Fac. Agric. Ain Shams Univ., Cairo, Egypt, 33 (2): 1101- 1114.

[3] Tharanathan, A. N. and Mahadevamma, S. (2003).Grain legumes-A boon to human nutrition. Trend in Food Science and Technology, 14: 507-518.
[4] Gross, R., Von Baer, E., Koch, F., Marquaro, R., Trugo, L. and Wink, M. (1988). Chemical composition of a new variety of Andean lupine (L. mutabilis) with low-alkaloid content. J. Food Comp. Anal, 1: 353- 361.

[5] Rodriguez ASL, Martınez AAL, Millan F and D'avila OG, (2005). Composition and functional properties of Lupinuscampestris protein isolates. Plant Foods Hum Nutr. 60:99-107.

[6] Rincon, F., Martinez, B. and Lbaane, M. V., (1998).Proximate composition and antiutritive substances in chickpea (Ciceraretinm L.) as affected by the biotype factor. J. Food Sci.andAgric., 78, 382-388.

[7] Vmadevi, M., Pushpa, R., Sampathkumar, K.P. and Debjit Bhawnuik, (2012). Rice-Traditional Medicinal plant in India. Journal of pharmacognosy and phyto chemistry, 1(1):5- 12.

[8] Dilip, K. and Aditya, N. J. (2013). Nutritional, Medicinal and Economical Importance of corn: A mini Review. Research Journal of Pharmaceutical Sciences, 2 (7):7-8.

[9] James,K., Bults, C.A., Hardacre, A.K., Korlaard, J. P., Clark, S.M. and Scot, M.F.(2004).The effect of drying temperature on the nutritional quality of new Zealand grown maize or growing rates. J. Sci. Food Agric., 84: 147-154.

[10] Vaidenhiand, M. P. and JoShiv, M.K. (1984).Effect of for tification of triticare with puse, on the preparation of some common Inddia recipes. J. Food Sci.Techno. 21: 403. 
[11] Farag, R.S., Au-Raiia, S. H., El Desoky G. E. and El-Baroty,G S. A. (1991).Safety evaluation of thyme and clove essential oils as natural antioxidants. African Journal of Agriculture Science, 18(1):233-237.

[12] Fasseas, M.K., Mounlzouris,K. C.,Tarantilis, P. A.,Polissiou,M. and Zervas,G. (2007).Antioxidant activity in meat treated with oregano and sage essential oils. Food Chemistry, 106: 11881194.

[13] Coma, V. (2008).Bioactive packing technologies for extended shelf life of meat-based products.Meat Science, 78: 90- 103.

[14] Altamann, H. J., Grunow,U.,Mohr, H.B., Richter, R.N. and Wester,P. W. (1986). Effects of BHA and related phenols on the forestomach of rats.Food Chemistry and Toxicology, 24: $1183-1188$.

[15] VanEsch, G. J. (1986).Toxicology of tert-buylhydoquinone (TBHQ).Food Chemistry and Toxicology, 24:1063- 1065.

[16] Shahide, F., Janitha, P.K.and Wanasundara, P. (1992). Phenolic antioxidants. Critical Review in Food Science and Nutrition, 32: $67-102$.

[17] Haas, J., Bellows L., and Li J., (2014). Gluten-free diet guide.Food and Nutrition Series Health. Fact Sheet No. 9.375.

[18] Holownia, K. I., Chinnan, M. S., Erickson, M. C. and Malikarjunan, P.(2000).Quality evaluation of edible filmcoated chicken strips and frying oils. J. Food Sci.,65:10871090 .

[19] Nahed, M. M., Atta, H. M. A., Mohamed and Awatif, I. Ismaeil. (2004). Effect of some coating application methods used for shallow- fried chicken breast fillets on lipid uptake and frying stability of shortening. Minia J. of Agric. Res. and Develop, (24) 2: 229- 262.

[20] A.O.A.C. (2000).Official Methods of Analysis of the Association of Official.Analytical Chemists international $17^{\text {th }}$ edition international, Maryland, U.S.A.

[21] Mukprasirt, A., Herald, T.J., Boyle, D.L. and Boyle, E. A.E. (2001).Physicochemical and microbiological properties of selected rice flour based batters for fried chicken drumsticks. Poultry Science, 80:988-996.
[22] American Public HealthAssociation.(1992). Standard methods for the examination of dairy products.American Pub1. Health Assoc. Inc. $16^{\text {th }}$ Ed., Washington D.C.

[23] Molannder, A.L. (1960).Discernment of primary test substances and probability to judge food.Iowa State University press, Ames, Iowa, U.S.A.

[24] S. A. S. (1987).SAS/ STAT. Guide for personal computers, Version 6 ed., SAS Institute, Cary NC, USA.

[25] Cerning-Beroad, J. and Filiatre, A. (1976). A comparison of the carbohydrate composition of legumes seeds: Horsebean, peas, lupines. Cereal Chem, 53: 968- 978.

[26] Cobos, A., Veiga, A. and Diaz, O. (2000). Chemical and fatty acid composition of meat and liver of wild ducks (Anasplatyrhynchos). Food Chemistry, 68 (1): 77-79.

[27] Liu, Y., Xu, X. L. and Zhou, G. H. (2007).Changes in taste compounds of duck during processing. Food Chemistry, 102 (1): 22-26.

[28] Salyakov, A. and Skog, K. (2002). Screening for heterocyclic amines in chicken cooked in various ways. Food and Chemical Toxicology, 40 (8):1205- 1211.

[29] Pokorny,J. and Reblova, Z. (1999). Effect of food components on changes in frying oil. Food Techn. Biotechn., 37(2); 139143 .

[30] Bagamboula, C. F., Uyttendaele, M., andDebevere, J. (2004).Inhibitory effect of thyme and basil essential oils.Carvacrol, Thymol, Estragol, linalool and P-cymene towards Shigellasonnei and S. flexneri. Food Microbiology, 21: 33-42.

[31] Dorman, H. J. D. and Deans, S. G. (2000). Antimicrobial agents from plants: Antimicrobial activity of plant volatile oils. Journal of Applied Microbiology, 88: 308-316.

[32] Cunningham, F. E. and Suderman, D. R. (1981).Use of batters and breading on food products-a review.In Quality of Poultry meat.Spelderholt Inst. For Poult. Res. Beeckbergen, the Netherlands. 